\title{
MULTICOINTEGRATION AND SUSTAINABILITY OF FISCAL PRACTICES
}

\author{
LORI LEACHMAN. ALAN BESTER. GUILLERMO ROSAS, and PETER LANGE
}

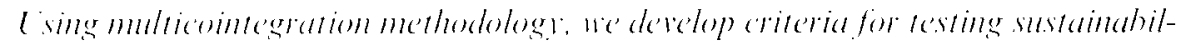

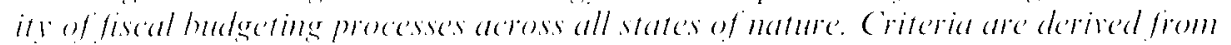

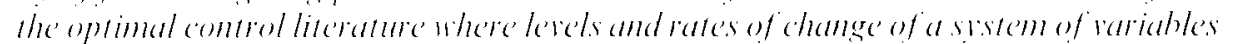
are deferminamts of policy reypense. The appropriate policy response mechamisms are

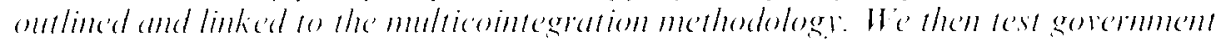

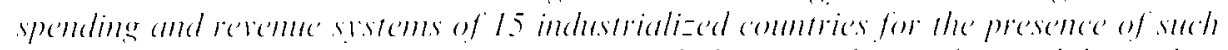

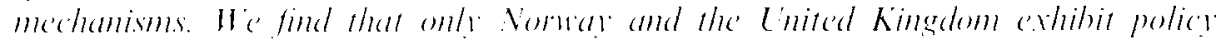
reyponses that are comsistem with ont riteria. (JEL H6, E62. (22)
\end{abstract}

\section{INTRODUCTION}

Governments are charged with the responsibility of crafting national budgets. Over time budgets tend 10 move between balance. surplus, and deficit. These fluctuations result from the fatet that all too often a government makes financial decisions in one year that hate implications for spending commitments and revente streams a number of years down the road. Thus. responsible govermment budgeling involves examining the budget position over time, that is. engaging in intertemporal budgeting. Feonomists gencrally utilize two criteria to assess the intertemporal budgets sustainablity: does the government run persistent deficits? It so, what is the resulting level of debl".

Are these two criteria sufficient to make predictions regarding budget sustainability? Recent work by Bohn (1995. 1998) and Ball el al. (1908) silgerests that budgets are lar foo complicated to be evaluated with respect 10 deficits and debt alone. These atuthors hate shown that persistent deficits and accumulat tion of debt does not necessarily imply that

Lewtmem Protesser at the Pratuce and Director of the

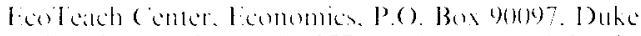

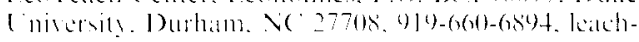
mandecoln.dukc.cilu.

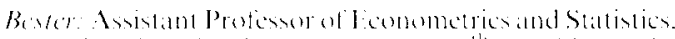

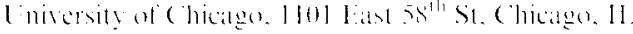
0016,37

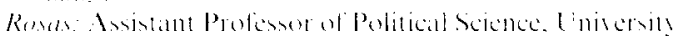

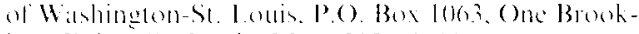

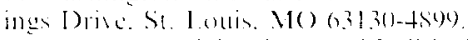

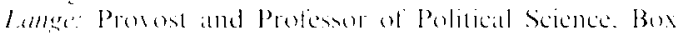

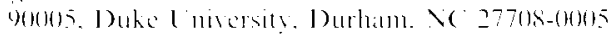

the debt is unmanageable and, hence, fiscal processes unsustainable. The implication of their work is that the standard approach to testing whether government adheres to its intertemporal budget constrant. cointegrattion analysis, does not provide sufficient criteria for detemining whether the fiscal process is truly sustainable.

Consequently, in this article we develop a more encompassing set of criteria under more rallistic assumplions for determining whether a country exhibits a sustainable budgeting process. Our criteria for sustamability are based the multicointegration approach lirst presented by (iranger and Lee (1989. $1990)$ and further developed in Engsted, (jonralo and llaldrup (1997) and Haldrup (1998). The budgeting practices of 15 industrialized countries (Belgium, Canada, Denmark. Finland, France, Greall Britain. Greece, Italy, the Netherlands. Norwaly. Portugal, Spain. Sweden, Switerland and the I Inited States) are evaluated in terms of the criteria. Our sample spans the modern ela. 190098.

We extend the intertemporal budecting literature by employing the multicomingeration liamework to develop the appropriate policy responses to deficits and debt accumulation and to test for their presenec. The methodology ansesses both the stock and how relationships

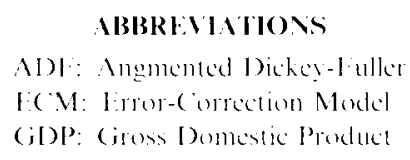


that should charalcterize sustainable fiscal processes when the datat are nonstationary. Cointegration between the spending-revente flow relationship is the first component of our criteria. Cointegration between the flow of reventic (spending) and the stock of debt is the second. Jointly theseconditionscharacterizemulticointegration between government spending and revenue. In the mult icointegration arse, thesystem is characteriad by at complex stock-flow equilibrium relationship that is not uncommon in intertemporal models of economic behavior. Such a relationship is typically associated with issues of optimal control where the kevels and rates of change of the variables making up the system are determinants of the policy response. Multicointegration can ensure that a country's budgeting strategy is sustainable in "bad" states of nature, that is. when the rate ofeconomic growth falls short of the real interest rate on sovereign debt.'

Bohn (1995) and Ball at al. (1998) point out that existing theoretical models that underpin traditional sustainability tests are too simple. Specifically. Bohn (1995) shows that the sustainability of imbalances in a stochastic setting involves satisilying an intertemporal budget constraint and a transversality condition that differs from that implicit in simple (deterministic) models. The transwersality condition requires that the limit of the debi discounted at a rate that is a function of the probability distribution of future debt and the marginal rate of substitution between present and futureconsumption be zero. This correct discounting is eritical in ecousomies where the rate of growth has been higher than the real interest rate. Such an economy can sustain persistent deficits ats high rates of economic growth lower the stochastic discount factor. thereby diminishing the debe burden. In such a setting. Ponzi schemes become Ponzigambles, which are "undesirable for some gencrations in some realiza-

1. Muldicointegration implics that in at bivariate i(l) system more than one cointegrathen vector maty exist such that the number of cointegrating vectors and the number of stochastic trends do not add up to the dimensions of the stitem as is the catse with cointegrated $1(1)$ merdels. This allows for a special case of polynomial comlegration that captures both fow and stoct relations sece. c.g.. (iranger and Lee 1989 and lingsted and Haldrup 1969). The presence of such a relationship indiciles that the hivatiate system is botand together by two equilibrat-

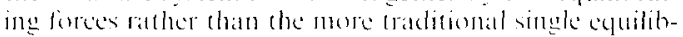
rimon redationship that chataderites comentionally coincegrated systems. tions of history when growh falls below the real incerest rate) but desirable bor all generattions in most realizations of history" (Ball cal. 1998.p.701). Therefore. Wearedereloping eriteria that assess whether the behavior that each country exhibits orer the sample period isconsistent with sustatinable budgeting policies resadleser of economic performance and ruling out defatult or intlation.

Results indicate that the budgeting prateliese of Vorwaly, the linited Kingdom. and the enited States are comsistent with multicointegration between government spending and revenues. Howerer. the systems of coeflicient estmates ate signilicantly different for each of these three countries leading to very different conclusions regarding the nature of policy response mechanisms and conseyuently fiscal sustamability. Results for Nerwas indicate that the country has on average experienced budget surpluses and has cul laxes in response to the accumulation of government salvings. For the lnited Kingdom. the system of coefficient estimates suggests that the British government has maintained deficits on as erage but hats moved to raise reventes in response to debl accumulation. In both of these countries the evidence is comsistent with the presence of the appropriate policy response mechanisms. Hence their budgeting practices meet our sustainability criteria.

On the other hand, although the l.S. results indialte that the spending-revenue system is multicointegrated. the evidence indicates that spending has consistenty exceeded revenues. yet the resulting debtaceumulation has beenaecompanied by declines in government revenues (rather than increases). This finding is not consistent with the sustamability criteria developed here. Nor is the evidence regarding 11 of the remaining 12 countries. Although I anish. IHinish. French. Spanish. and Swedish spending revente systems are cointegrated, the evidence indicates that they have persistenty run deficits and that they lack any systematic policy response to them. In the remaining seven countries there is no evidence of a fong-run relationship between government spending and reventes. In every case except Switzerland spending has persistently exceeded revenues. suggesting that debt accumulation is the norm.

The remainder of the article is organized as collows. Section II reviews the literature on intertemporal budgeting and sustainability of deficits. Section III outlines the model 
and derives the theoretical constructs to bo tested. Section IV presents the multicointegrattion methodology. In section $V$ the multicointegration results are presented and discussed. Section VI concludes.

\section{BACKGROUND}

Many researchers have explored the issue of solvency and Ponzi financing in a deterministic setling. Hamilton and Havin (1986) were amone the first to adopt the intertemporal budge constraint approach to empirically investigate the issue. They examine the 1962 84 period for the einited States concluding that lac datta support a binding constraint. Wilcox (1987) and Kremers (1989) extend the work in this atrea, contraddicting the Ilamilon and liavin conclusion.

Ising the cointegration approach, studies by Trehan and Walsh (1988. 1990). Smith and Zin (1988). Hakkio and Rush (1991). Hatug (|99|). Ahmed and Rogers (1995). and Leachman (1990) produce contlicting evidence surrounding the issue of governments use of Ponzi linancing. Trehan and Walsh and Hatuge find evidence supporting intertemporal fiscal balance for the linited States Hakkio and Rush and lecatoman do not. Smith and Zin explore the intertemporal liseal balance of camada producing eridence that supports a sustainable fiscal pith orer the long run. l- imally. the work of Ahmed and Rogers inspects the fiscal balance of both the Enited States and the lnited Kingdom. The authors conclude that the evidence is consistent with both countries obeving their intertemporal budget constratints.

With the execption of Ahmed and Rogers (1995). all of the models that underpin the work ate derived in a decrministic setting. gencrally under the assumption that economies are dynamically efficient and the rate of growth is less than the sate interest rate? More realistically the em isomment is stochatstic and uncertainly is present. In such a setting. sustamability of fiscal deficits is more complex. Bohn (1995) develops the theoretical considerations for this secenario, and Ahmed and Rogers demonstrate that under certain

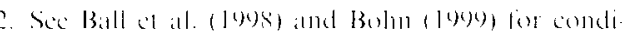

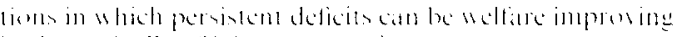

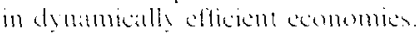

conditions cointegration remains a sufficient condition. Ball et al. (1998) further explore the issue of sustamability. They produce evidence for the United States indicating that the probability of a bad outcome, defined as rates of growth below the real interest rate. is between $10 \%$ and $20 \%$. Bohn (1998) outlines and lests for a corrective mechanism in the budgeting process that enables an economy 10 sustain imbalanes given bald outcomes. He finds that the United States exhibits such a budgeting strategy.

Von Hagen and Harden (1994). Milesi-Ferretti and Razin (1995. 1996), and Uctum and Wickens (1996) also explore the sustainability issue. These studies look at the fiscal processes of an array of countries and factors that influence a countrys ability to sustain persistent imbalaness. Milesi-lerretti and Ravin locus on factors that influence sustainability (through the promotion of growth) and directly alfect the willingness to pay for debt in a number ol developing countries. Von Hagen and Harden and lictum and Wickens inspect the sustamability of the actual fiscal pratetices in the United States and various European countries. Von Hagen and l larden conclude that France, Germany, the Inited Kingdom. Luxembourg. and the Netherlands exhibit liscal practices that atre "close" lo sustainable for the entire sample period (1970) 84). Denmark. Belgium, and Ireland stat the sample period with unsustainable processes but improve their performance in the loses Italy. Greece. Spain. and Portugal exhibit unsustanable practices. The empirical evidence produced by Jetum and Wickens indicates that the fiscal stance of Denmark. the Netherlands, and I reland is sustainable, whereas the fiscal processes exhibited by the United States, Spatin. Italy. Belgium. and Portugal are not.

\section{THE MODEL}

In this section we build on the work of Bohn (1995, 1998). Ahmed and Rogers (1995). and (iranger and Lee $(1990) 10$ develop a set of criteria by which government budgeting processes can be considered sustainable in all states of nature. We first assume that for all t there exists a unique nonnegative process $\left\{M_{1}^{\prime}\right\}^{\prime}{ }^{\prime}$. This process, called the stochastic discomnt factor, is defined so that $M_{t}^{\prime}$ l almost surely and if $\left\{l_{f}, v\right\}_{n}^{\alpha}{ }_{n}$ is a sequence 
of random payof's beginning in period then its value in units of period $t$ consumption is

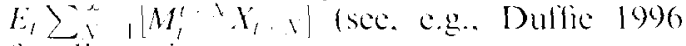
for discussion).

To derive the relationships relevant to this article, we begin with the government's budget constraint It is expressed as

$$
\text { (1) } \quad\left(i_{1}+\left(1+i_{1} 1\right) B_{i},-R_{1}+B_{i}\right.
$$

where $;$ - government spending. which includes purchases of goods and services as well as transfers:,$\quad$ a stationary sale rate of interest: $B$ govermment bonds of one period matturity: and $R=$ total government revenue. comprised primarily of taxes.

Substituting forward for $B_{l}$ in equation (1) and rearranging. we obtain the following presen value relationship:

$$
\begin{aligned}
& \text { (2) } \quad(1+i, 1) B_{i}, \quad E_{i} \sum_{i}^{2} H_{i}^{\prime} \cdot
\end{aligned}
$$

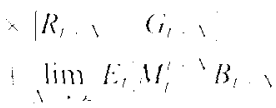

Equation (2) simply says that the current value of govermment debt is equal to the expected present value of all future primary surpluses. plusa limitingterm representing the asymptotic expected present value of the governments debt. We can ensure that the limiting term on the right-hand side of (2) is nonnegative by assuming that the government does not allow individuals to engage in Ponzi sehemes algainst it. Furthermore, if the government is satisfying its budget constraint intertemporally. it cannot asymptotically lave a debt with positive expected present value. Hence the time 1 expeced paths of spending and revenues are sustainable if the limiting term on the righthand side of (2) is equal to $/$ ero.

In a deterministic setting and/or one charasterized by risk neutrality, the stochastic discount factor is constant and equal to $1 /(1+$ i). and the condition for sustamability reduces

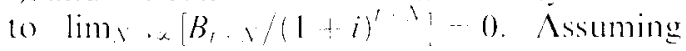
this environment and nonstationary datal the restriction hats been empirically interpreted as reguiring a cointegrating or long-run equilibrium relationship between spending and revenues with a coelficient of cointegration less than or equal to one. The reasoning behind such tests is typically based on rulingout a decemin- istic bubble in government debt. I lowerer, in at stochastic enviromment. Bohn (1995) hals demonstrated that exen if government debt is riskless and pays a constant rate of return $i$. $\lim _{3 .}\left[B_{i}, 1 /(1+i)^{t}\right] \quad 0$ does not necessallily imply that $\left.\lim _{x} . L_{1} M_{,}{ }^{\prime} B_{1}, 1\right] 0$ The problem here is that the correct discount factor is a function of state contingent claim prices that can become arbitrarily large in bald (low GNP) states. Even il government debe grows al a rate smatler (larger) than $i$, the risk of a sharp decrealso (increase) in (iNP can still caluse the limiting term to be inlinite ( $/$ ero).

lortunately. Ahmed and Rogers (1995) show that under relatively general conditions. tests of cointegration arestillappropriate. They demonstrate that under certain conditions on the stochastic discount factor and the risk premia on government revente and spending. limy . . E El $\left[H_{t}^{\prime} \cdot B_{t}, 1,0\right.$ holds if and only if the system $\left(R_{t},\left(i, i_{1}, B_{1},\right)\right.$ is cointegrated with the cointegrating rector $(1,1.1$ ) (sec Ahmed and Rogers 1995 for a full discussion). Moreover. these atuthors point out that combegration. henee stationarity of the deficit. does not necessartily imply that the natlonal debt must eventually be paid off to be sustainable. Sustainability as it is defined here is an astmptotic property: Even if revente and spending end to dritt together in the long rum. delicits and surpluses may grom arbitraily latoe over short lime horizons. for example. Ball et al. (1998) characterios budget deficits as Ponzi gambles in which the govermment "bets" that aggregalcincome will grow fast enough lomake the debt-income ratio ball ststematically over time. An important result is that the laterer the debt-inconc ratio grows the kess certatin a Ponzi gamble is losuceed and the more likel. it isthat statecontingent clams prices henecthe correct discount liactor, rise.

Therefore. we develop furber criteria tor sustamability. Let $i_{,}^{*} \quad\left(i, \pm i, \beta_{i}\right.$, Inother words. (; is gorenmonte expenditures includ ing interest payments. "Suppose that the vector process $\left(G_{i}^{*}, R_{f}\right)$ is cointegrated. Specifically. let (i, and $R$, be $l(1)$ and assume there exists a real constant $A$. the cocllicient of cointegration or cointergrating sealar. such that $=$, $;, A$

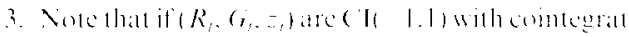

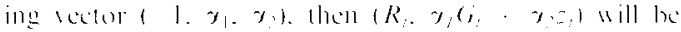

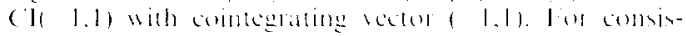

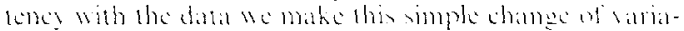
bles heve. 
$R$. I(0). The valiable $=$, then is a measure of short-run deviations from the eyuilibrium (combegrating) relationship. In this system $\Rightarrow$ represents the current period budaet deficit (surplus). The accumulation of $=$. L' sents government debl (salvings). (iranger and lee(1989. 1900) define $\left(i_{,} . R_{t}\right)$ to bemuldicointegrated if $\left.h, \quad(l), \quad i R_{i}\right) \quad I(0)$. Note if (i, and $R$, alte multicointegrated. $D$, and ( $i$, will also be cointegrated.

The simplest criterial for interemporal balance require that $(;$, and $R$, be comlegrated with cointegrating vector $($ 1. 1). This implies that $(i$, and $R$, are $I(1)$ processes with the following representations

$$
\Delta\left(i_{1,1} \quad a_{1},+v_{1,1,1} .\right.
$$

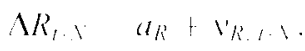

where $\Lambda$ is the first diflerence operater and

$$
\begin{aligned}
& V_{1}, A H_{1}-V_{(+1} \\
& I_{R, A} \quad \Delta H+I_{k 1, .}
\end{aligned}
$$

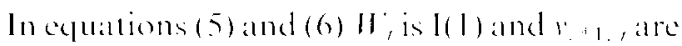
It-1) processes. $\ell^{*} \quad R_{0}\left(6^{*}\right.$. This isthestandard common lactor representation forcointegrated series In thiscase, one can think of 17 , as a state variable that summarizes time $f$ economic conditions. and $(5)$ and $(6)$ can be interpreted as the government's policy response rules. Sustainability oceurs when the government s spending and tax reventes depend on information that can be summaried by the same $I(1)$ informatlion variable. (hanges in government spending and revenues will then both depend linearly on changes in 11 ,

Similarly. $R$, and $(;$, will be multicomegrated if $r^{\prime}$ and $r_{6 *}$ ean be represented as

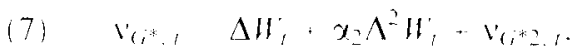

$$
\begin{aligned}
& \text { (8) } v_{R,}, \Delta H_{1}: x_{1} \Delta^{2} H_{1}+v_{R 2,}
\end{aligned}
$$

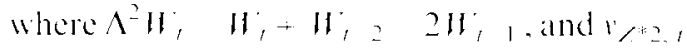
are $I(2)$ processes. and $x_{1}$. $x_{2}$ satisty $x_{1}$ $x_{2}, 0$. In this case. $R$, and $D$, will be cointegrated with cointeglating vector (1. - $-\left[x_{1}-\right.$ s. 1). liquations (7) and (8) can be thought of as more sophisticated policy response mechanisms in which the gorernment considers both the change and the rate of change in economic conditions in formulating its fiscal policy. This strengthens the equilibrium relattionship in a suble bul ponerful waly asymptotically, both the levels and the rates of ehange of the two series are tied together.

With this more sophisticaled policy response in place. taxes are increalsed and/or spending is decreased when the cumblative deficit becomes too large and/or the rate of increase is accelerating. This can be considered smilar to the production example in Granger and Lees $(1990)$ paper. Here the government laces quadratic adjustment costs lor spending and revenues as well at a cost of large deficits.

To be concrete. consider the following optimal taxation problem. Suppose that the govermment hats determined its optimal spending decision (including interest payments) as a sequence of policy lunctions $\left\{\left(f_{1, j}^{*}\left(I_{,}, j\right)\right\}_{, 0}\right.$ where $I_{l}$, is the time $t$ information set. By matnipulating tax rates, the government controls its time $t$ reventes $R$, to minimize

$$
\begin{aligned}
& L_{1} \cdot E_{i} \sum_{i=1}^{2}=\left(R_{1, i} \quad\left(i_{i, j}\left(l_{1, j}\right)\right)^{2}\right. \\
& +\left(\rho_{1}(l)\right)_{, j} \quad \kappa\left(i_{1, j}^{*}\left(l_{1, j}\right)\right)^{2} \\
& +\left(\varphi_{2}\left(R_{1, j} \quad R_{1, j}\right)^{2}\right.
\end{aligned}
$$

In this example the government balanes three costs in its budgeting decision: the cost of isstuing debt in the current period, a cost that oceurs when the cumblative deficil (or surplus) becomes large relative to the current size of govcrmment, and finally the cost of manipulating tax raltes to change revenues from period to period. Drawing on the results of Lee (1992), the solution is a sequence of revenues $\left(R_{t, j}\right)_{, j}^{x}$ that make the process $\left(R_{f}, G_{f}^{*}\right)$ multicointegrated.

This example is one of many ways in which multicointegration can arise in our system of variables. In more general models. the criteria can be interpreted als requiring that the government's policy response functions for reventes and spending follow the error-correction models (ECMs) in equations (7) and (8). If government is to satisly its budget constraint intertemporally. its reventes and spending decisions must depend on some common stochastictrend. Il the government istaking potential costs of a large cumulative deficit into account, its revenue and spending decisions 
will also depend on the rate of change in the common trend. For example, when the primary deticit is accelerating. the government takes preventativation (raisinglaxesand/or lowering spending) to prevent the eumulative deficit from becoming too large in future periods.

The relationships outlined reflece the policy response that results from an optimal control mechanism where adjustment costs are quadratic. In conjunction with restrictions on patrameter estimates outlined next they define our sustainability criteria.

\section{METHODOLOGY}

To assess a country's liscal performance in terms of our criteria, the multicontegration framework first presented in Granger and Lee (1989. 1990) and further developed by Engsted el al. (1997) and Haldrup (1998) is employed. Where multicontegration is rejected traditional Engke and Gianger (1987) cointegration tests are executed. The cointegration and multicointegration methodologies are based on the single-equation approach pioneered by tungle and Granger. Work by Zhou (2001) and Gonzalo and Lee (1998) has shown that single-equation test statistics are generally more robust.

Consider two series $x$, and $1 \%$. Typically, it is assumed that they are stationary. in which cisse they are integrated of order tero. In many macrocenomic time series. however, it is more commonly the calse that series are $I(1)$. In the previous section we have outlined the conditions under which (the generic variables) $x, \cdots I(1)$ and $y,-I(1)$ are found to be (multi) cointegrated.

Multicointegration is a very special form of I(2) cointegration. Engle and Yoo (1991) and Johansen (1995) among others have explored the more general properties of $I(2)$ systems. but until quite recently the multicointegration property and methodology has not been well developed. Lee (1992), Engsted and Johansen (1997), and Engsted et al. (1997) point out that the presence of multicointegration invalidates tradditional methods of testing for cointegration. Therefore, Fngsted et al have developed a single-equation procedure for testing multicointegration that exhibits quite lavorable statistical properties. It is an extension of the Engle and Granger (1987) two-step procedure to the catse of $1(2)$ variables. We employ this approach. ${ }^{+}$It exploits the filce that multicointegration implies a particular form of $1(2)$ cointegation. In so doing it simultancously tests both levelsoleointegration and produces test statistics with distributions that ate well known.

The intial step requires estimation of the following regression:

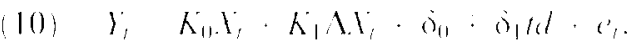

where $y, D_{1}, y, l(2), y, D_{i}, x, l$ (2). Id trend. and $A .1$, conded be replaced by $A \%$. This is followed by tests of " the order of cointegration. In that a number of cointegration possibilities exist a variely of hypotheses may be relevant for testing. However in most practical situations I(2) var-

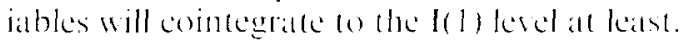
Therefore, we test the null hy pothesis that the I(2) variables cointegrate to lol) level but no further cointegration occurs such that ${ }^{\prime}$ ' is I(1). The distributions of the lest statisties depend on the number of $I(1)$ and I(2) regressors. $m_{1}$ and $m_{2}$. respectively. Additionally. dederministic components included in (10) will allfect the distributions. Critical values for various combination of $m$ and $m$, are presented in Italdrup (1994) lor the case with a constant and in Engsted et al. (1997) for trend and quadralic trend catses.

In equation (10) the $Y_{1}, Y_{\text {, variables ale } \mathrm{I}(2)}$ by construction. whereas $\Lambda . X_{\text {, is }} \mathrm{I}(1)$. In terms of our system of variables. Y represents accumulated spending. $T$ is the alecomulated resenue series and $\Delta . \mathrm{I}$ is government revenues. In the presence of multicointegration. $K_{11}$ is at super-super-consistent estimate of the first coefficient of cointegration converging to the true value al a rate of $O_{,}, T^{-}, K_{1}$ is a superconsistent estimate of the second stock-flow

4. We hate also somated at moditied weram of the

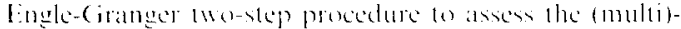
coindegration property. Those results actempanded by an explanation of the procedural molitications, atre athatable on reyuest.

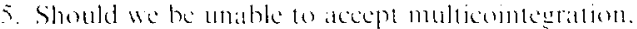

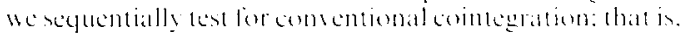
we test the validity of the null hypothess. Where we ato

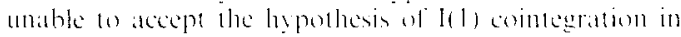
conventional tests. the mull hypothesis in the ks for mul-

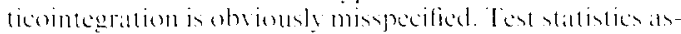

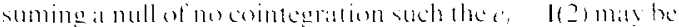
comstreted in principle but are not currentls arabible.

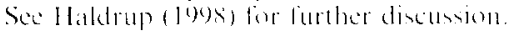


cointegrating relationship exhibiting $O_{p}(T \quad$ ) convergence.

Becaluse the enviromment is stochatstic, suslamable budgeting does not impose any a priori restrictions on the magnitude of $K_{0}$. It caln be greatter than. equal to. or less than one. If it is less than one on average reventes outpace spending keading to the accumulation of surpluses. If it is equal to one. on averalge the budget is in balance. If $K_{11}$ is greater than one. on average spending outpaces revenues and the government may be engaged in a Pomi gamble requiring lax increases and/or spending culs in had stales of nature.

Given $K_{0}, 1\left(K_{0}, \ldots 1\right)$, our sustamability criterial requires that government reventes and the present value of debe be positively (negatively) related that is, $K_{1}$, () $\left(K_{1}, 0\right)$. The postive (negative) nature of the relationship ensures that revenues rise (fall) to aceommodate rising levels of debt (savings). These conditions ensure that neither the government nor the private sector engage in a Ponzi scheme or gamble.

(iranger and lece (1989) hate shown that for a hivariate multioningerated system lac Ms can be represented by

$$
\begin{aligned}
& \text { Ni, } \quad \eta_{1}=1 \quad \gamma_{2} h_{i} \\
& \text { liaged }(\Delta x, \Delta y)+c
\end{aligned}
$$

$$
\begin{aligned}
& \text { Ai } \quad \because=1 \quad \% h \\
& \text { lagged }(\Lambda r, \Delta y)+\varepsilon_{j} \text {. }
\end{aligned}
$$

The changes in $x$, and 1 , atre related to the lagged comegration errors with the necessary condition that at least one component of each pair of $\gamma$ and $\gamma$, is nomero. Inclusion of the second errot correction term. hi n. enables the system to be more robust to disturbances. The evidence produced by the Le M provides information concerning the nature of the short-run dynamics necessary for achieving the long-run equilibrium. For a more complete discussion and technical derivation see Johansen (1992. 1995). Paruolo and Rahbek (1996). and Engsted and I Ialdiup (1999).

\section{MULTI/COINTEGRATION RESULTS}

The data utilized in this study ate drawn exclusively from oreanisation lor leonomic (o-operation and Derelopment Feonomic Oulook seriss. They are annual observations in real domestic currency units from 1960 through 1998 roughly because 1960 "seemed to be a watershed, and the growth in public spending after that year was quite dramatic" (Tanzi and Schuknecht 1997. p. 165). The government spending series is composed of expenditures across all levels of government. Similarly. the tax revente series is an aggregate of government receipts from income tax, social security tax or its equivalents. eorporate tax. and indirect taxes at the various government kevels. These series represent consolidated govermment revenues and expenditures, thereby producing a general or consolidated deficit and debl series."

The series have been adjusted to produce two measures of spending and revenues. In general all reported test statisties reflect estimations undertaken using real values/gross domestic product (GDP). The isstes ratised by Bohn (1995. 1998) and Ball et al (1998) are framed in terms of this meisure. However. for Norway, the Netherlands, and the Inited Kingdom real values per capital ate employed becatuse the systems comprised of real spending/CiDP and real revenue/GDP do not meet the I (1) eriterial (see later discussion). Real values per capital are real values deflated by population. Mc Callum (1984) and Fasterly (20)00) mote that this meastere maly be pertinent becalusc population growth may lead economic growth and help to service debt. Ciraphs of the system(s) of the spending and reventie varbables from cach country are available from the atuthors on recpuest.

In Table I the alugmented Dickey-fuller $(\triangle D F)$ statisties are presented. They are accompanied by the atrerage growth rate for cach country over the simple period. ${ }^{7}$ The

6. For the vetherlands the datia simple spatns 1970

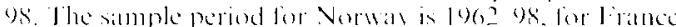
and the e niled Kingdom it is 1963 og and for Span in is 196t-1948. For the remaining 10 countries the sample pe-

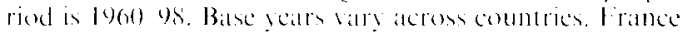

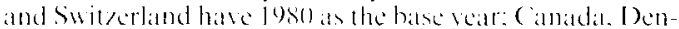
matk. and Spain use losen: (ireece usea loss: the balse year for Belgium. Finlande Itals. The Velherlands. Norwas, Porlugat and the lnited kingeden is 1940): Sweden and

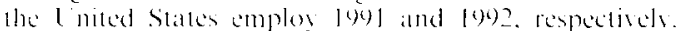

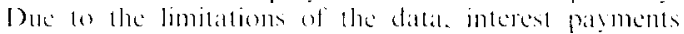
are mol separately detlated in the expenditure sertes.

7. It is important lo mote bath in our simple of coun-

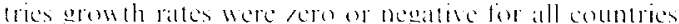
exeept lomwaly between 1974 and 1975 . in the early

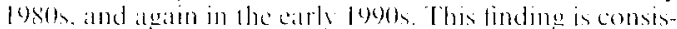

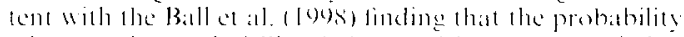

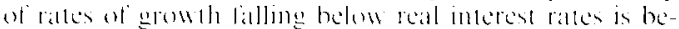
1wen 10", and $20^{\prime \prime}$. 
TABIE 1

ADF Statistics

\begin{tabular}{|c|c|c|c|c|c|c|}
\hline & & $\begin{array}{c}\text { Real per } \\
\text { Capita Spendling }\end{array}$ & $\begin{array}{c}\text { Real per } \\
\text { Capita Revenues }\end{array}$ & $\begin{array}{l}\text { Spending } \\
\text { (il)P }\end{array}$ & $\begin{array}{l}\text { Revente } \\
\text { (iI) }\end{array}$ & $\begin{array}{l}\text { Are. Growth } \\
\text { Rates ("14) }\end{array}$ \\
\hline \multirow[t]{2}{*}{ Bclgium } & AI)I $(1)^{*}$ & 1.3128 & 1.0974 & $1.01+10$ & 2.29 .47 & $\therefore 1$ \\
\hline & $A() I(1)$ & 0.9251 & 0.6205 & 0.7471 & 0.801 .3 & \\
\hline \multirow[t]{2}{*}{ (anitala } & ADI $(1)^{*}$ & 1.5453 & 1.5052 & $1 .+128$ & 1.733 .3 & 3.4 \\
\hline & $A D]:(1)$ & 0.6813 & 1.0615 & 1.77117 & 1.7719 & \\
\hline \multirow[t]{2}{*}{ Dommark } & $\Delta[D] \cdot(1)^{*}$ & 0.9385 & 0.868 .85 & 1.6 .586 & 2.4610 & $2 x$ \\
\hline & ADI:(1) & 1.2500 & 2.8375 & $0 .+250$ & 1.16937 & \\
\hline \multirow[t]{2}{*}{ linland } & ADI: $(1)^{*}$ & 0.6135 & 0.0518 & 1.2018 & 0.7429 & 3.3 \\
\hline & ADI:1) & $2.10(00)$ & $3.1+11$ & 3.603 .5 & $3.6 \times 10$ & \\
\hline \multirow[t]{2}{*}{ France } & ADI: $(1)^{*}$ & 1.4550 & $1.66,35$ & $1.070\}$ & 0.5583 & $\therefore 2$ \\
\hline & $A D](1)$ & 1.0460 & 0.3059 & $1.9(6)(11)$ & 1.706 .3 & \\
\hline \multirow[t]{2}{*}{ cireces } & $\Lambda()] \cdot(1)^{*}$ & 0.60889 & 0.9230 & $1.19+41$ & 11.5457 & 4.8 \\
\hline & $A I) \mid(1)$ & 1.4714 & 25266 & 1.73 .49 & 30150 & \\
\hline \multirow[t]{2}{*}{ Jualy } & $A D P(1)^{*}$ & $1.2(4) 5$ & $0.8(9+4)$ & 1.44 .4 & 10.3805 & 3.4 \\
\hline & AI)小.(1) & 0.9312 & 1.7331 & 15133 & 1.71123 & \\
\hline \multirow[t]{2}{*}{ Netherlinds } & ADI:(1)* & 296,15 & 2.86004 & 12.5520 & 19.7231 & 2.8 \\
\hline & $\Delta D H(1)$ & $0 . x+52$ & 1.99 .71 & $|10.550|$ & 17.8580 & \\
\hline \multirow[t]{2}{*}{ Norwaly } & $A[)]:(1)^{*}$ & 0.5894 & 1.7686 & 23301 & 11.2812 & 4.2 \\
\hline & $A[)](1)$ & 2.3266 & 6.4706 & $1.32(90)$ & $1: 10713$ & \\
\hline \multirow[t]{2}{*}{ Porlugial } & $A D)](1)^{*}$ & 0.6857 & 1.72 .31 & $10.64+6$ & 11.1554 & 4.7 \\
\hline & AI)I:(1) & 28145 & 1.63944 & $2.0(16) 4$ & 3.88436 & \\
\hline \multirow[t]{2}{*}{ Spaill } & ADI $(1)^{*}$ & 0.70 .57 & $11.3+74$ & 1.27115 & 1.2595 & 4.2 \\
\hline & AI)H:(1) & 2.0775 & $1.7++10$ & 1.1960 & $11.211 \times 2$ & \\
\hline \multirow[t]{2}{*}{ sweden } & $A I) I^{\prime}(1)^{*}$ & $1.937 x$ & $1.57+6$ & 1.5281 & $2.346,5$ & 25 \\
\hline & $\Delta[D]:(1)$ & 0.4 .574 & 1.96x & 0.7058 & $1.4 i+4$ & \\
\hline \multirow[t]{2}{*}{ Swit/rland } & $A I)]:(1:$ & $(1 .(x+4) 1$ & 0.5736 & $(1.7584)$ & 11.470 & 23 \\
\hline & $A I)(1)$ & 2.4298 & $1.5+01$ & 2.96711 & 2.1961 & \\
\hline \multirow[t]{2}{*}{ l nited kingdom } & AI)F( $(1)^{*}$ & 1.3 .368 & 1.1354 & 2.42001 & 3.7368 & $2+$ \\
\hline & AI)F(1) & $2.192-4$ & $3.67+3$ & $20(109010$ & $\therefore 4477$ & \\
\hline \multirow[t]{2}{*}{ Inited Statter } & ADl:(1)* & 0.5089 & $0.3+597$ & $2.3(0,51)$ & $1.5(1,1)$ & $\therefore 2$ \\
\hline & $A D P(1)$ & 2.7028 & 3.5110 & $+.20(10)$ & $2.9(1+4)$ & \\
\hline
\end{tabular}

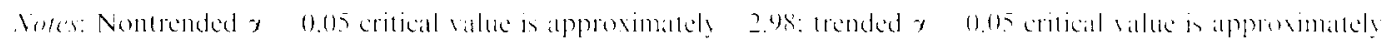
3.59. *indicites no lacend.

$\triangle D F^{*}$ statistics test for the presence of a tunit root with and without a trend and allowing for a drilt in each series. The two measures of government spending and revenues generally exhibit unit roots with a trend for all countries." However, for finland the real/(jD) series are nontrended. Similarly. in Portugal revenue/GDP is nontrended. while spending/ GDP is nontrended, for the Inited States In Norway and the United Kingdom revenued

8. For I inlated the real/(j)P series ate nontrended. Similarly. in Portugal reventachesple is montrended whereas yending/(io) is nomtended for the linited Silles.
(iD) is $I(0)$. Whereas both real/(iD)P series are stationary in the Netherlands.

Next we accumblatte the appropriate series to produce new series that are I(2) by construction. This is followed by tests for multicointegration between gowernment spending and receipts. Results of multicointegration tests and. where appropriate. the corresponding ECMs are presented in Tables 2 and 3.

Inspection of Tables 2 and 3 indicates that multicointegration is present in the tiscat systems of Norway the United Kingdom and the Inited States. However. the results indiciate that the nature of each count ry tiscal budgeting process is quite different. First consider Norwaly. The estimaled values of $K_{0}$ and $K_{1}$ 
T IBI E 2

Muldicointegration Tests

\begin{tabular}{|c|c|c|c|c|c|c|}
\hline & $k_{11}$ & $\mathbf{k}_{1}$ & Con & Ird & $\mathrm{NIPF}$ & I)W \\
\hline Belgium: real/(i)P & $|(x)| y$ & 5.3740 & 1.SSI: & $11.25: 2$ & 301465 & $0.5(10) 3$ \\
\hline (antudia kial/(i) ) & $1.01+4$ & $1.12 x+$ & (1. 44.36 & $11.21+7$ & 2.2111 & 0.17010 \\
\hline Demulth räl/( il)P & 1.17 .50 & 1.2633 & $(1 .+40)$ & 1). $10: 36$ & 3.9332 & 0.20180 \\
\hline linland real/(i1)l & 1.3 .3 & 2.2193 & $(1.72 \times 2$ & 11.1740 & 3.7313 & 0.3005 \\
\hline |ramer ral/(il)|' & $1+315$ & $0.000(1)$ & 0.1022 & 11.2118 & $3.0+771$ & 0.2331 \\
\hline (ivecer reitl/(il) & 2.30014 & 1.2673 & 11.41 .34 & 11.3967 & $2 \times 7 \times 9$ & 0.231 .3 \\
\hline$|1 i t|$ rail/(;i)|" & $2.1+84$ & 12.780 .8 & $\therefore+424$ & 11.61314 & 3.17 .90 & 0.7228 \\
\hline Vedherlands rail per capita & $1.15+4$ & $0.02+1$ & 11.0311 & 11.610126 & 1.1101 & $0.2+407$ \\
\hline 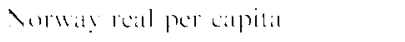 & (1). $9 \div 72$ & 1.507 & $0.06+4)$ & $11.0(1) 1+$ & $4.2 \times 79$ & 0.3747 \\
\hline Pollugald reabl/(il)P & 1.21)24 & $1 .+3.86$ & 10.2424 & 0.0703 & $1 .(1+27$ & 0.3150 \\
\hline Spain real/(il)P & 1.1915 & 0.3217 & 11.07114 & 0.00 .55 & s.risos & 0.2772 \\
\hline Sincken $r(i 1 /(i 1))^{\prime}$ & $1 .+11 \mathrm{~s}$ & 2.713 .3 & 1.066 .3 & 0.23 .2 & 3.7552 & 0.3070 \\
\hline Sแ ilハlatud rail/(;) & 1.19336 & $0 .(1,504)$ & 11.16 .36 & 1.01087 & $3.6,95+$ & 0.1675 \\
\hline I nited kingdom rall per cappital & 1.2764 & 0.3052 & 0.001 .27 & 0.00009 & $\therefore+704$ & 0.2780 \\
\hline l niked Slints rail/(il)P & 1.2336 & 1.2474 & $(1.334 \div$ & 11.1530 & 4.5851 & 0.4480 \\
\hline
\end{tabular}

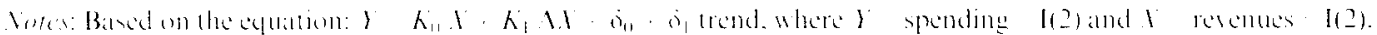

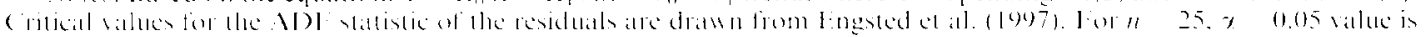

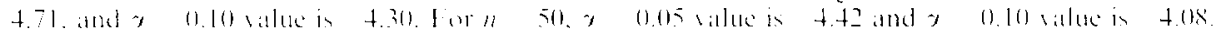

are 0.96 and 1.51. respectively. The lace that $K_{0}$. I indicates that reventes have oupaced spending over the sample period. The negative value on $K$ indicales that reventes have lallen as surpluses have mounted. The results are consistent with sustamability and the conjec- ture that the Nomegian government has not allowed the private sector to rum a Pomi scheme algainst it.

Next consider the Inited Kingdom. The estimated value of $K_{1}$ is 1.28 . indicating that on average spending has exeeceded reventes.

TABI.E 3

Multicointegration Lirror Correction Models

\begin{tabular}{|c|c|c|c|c|c|c|}
\hline & $\alpha$ & $\gamma_{1}$ & $\gamma_{2}$ & $\mathbf{B}_{1}$ & $\mathbf{B}_{2}$ & $r^{2}$ \\
\hline \multicolumn{7}{|l|}{ Nomil! } \\
\hline .15 & $\begin{array}{l}11,(10115 * \% \\
125+(1) S)\end{array}$ & 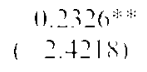 & $\begin{array}{l}1.1 .322 \\
1 \quad 1.04(01)\end{array}$ & $\begin{array}{l}0.3 .306 * * \\
(2.1327)\end{array}$ & $\begin{array}{c}0.1538 \\
10.32221\end{array}$ & 0.13 \\
\hline$\backslash R$ & $\begin{array}{l}(1.1112+4 * * \\
(3.2 \times 25)\end{array}$ & $\begin{array}{l}(1.1528 \\
(1.2670)\end{array}$ & $\begin{array}{l}(1) .0503 \\
(0.31+8)\end{array}$ & $\begin{array}{r}0.3563^{*} \\
(\quad 1.6971)\end{array}$ & $\begin{array}{l}0.3032 \\
(1.4+(08)\end{array}$ & 0.114 \\
\hline \multicolumn{7}{|l|}{ I'nical kingdum } \\
\hline AS & $\begin{array}{l}0.61130)^{5 *} \\
(32.57594)\end{array}$ & $\begin{array}{l}(1 .+735 \\
(1.3119)\end{array}$ & $\begin{array}{l}1.28+99^{* *} \\
(10 .(690+1)\end{array}$ & $\begin{array}{l}2.2347 * * \\
(2.2705)\end{array}$ & $\begin{array}{l}2.1266^{* * *} \\
13.19261\end{array}$ & 0.1181 \\
\hline$M R$ & $\begin{array}{l}(1.01600)^{* *} \\
(3.9(1+1)\end{array}$ & $\begin{array}{l}(1.0 .335 \\
(0.4+52)\end{array}$ & $\begin{array}{c}0.0474^{* *} \\
1 \quad 2.06341\end{array}$ & $\begin{array}{l}0.2350 \\
(1.2447)\end{array}$ & $\begin{array}{c}10.22 \times 6 * \\
1 \quad 1.746(6)\end{array}$ & 0.23 \\
\hline \multicolumn{7}{|l|}{ I nifled Stilles } \\
\hline 1.5 & $\begin{array}{l}(1.0(1) 10) \\
(0.77 \times 6)\end{array}$ & $\begin{array}{r}0 .(0) 38^{* * *} \\
1 \quad 4.8370)\end{array}$ & $\begin{array}{c}0 .(10) 75 \\
(\quad 0.5702)\end{array}$ & $\begin{array}{l}(1.4894 * * \\
(3.3(19)\end{array}$ & $\begin{array}{c}0.00000 \\
1 \quad 1.1+211\end{array}$ & 0.40 \\
\hline$M R$ & $\begin{array}{l}12308+1 \\
11.23621\end{array}$ & $\begin{array}{r}8611962 \\
10.87221\end{array}$ & $\begin{array}{r}6752881 \\
10.56151\end{array}$ & $\begin{array}{r}2231 \times 11] \\
(0.1941)\end{array}$ & $\begin{array}{c}0.1270 \\
+\quad 0.69321\end{array}$ & $0.0 \mathrm{~s}$ \\
\hline
\end{tabular}

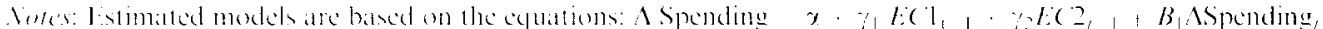

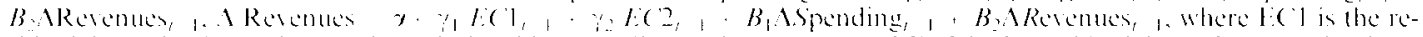

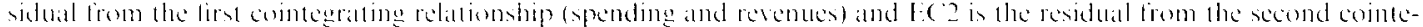

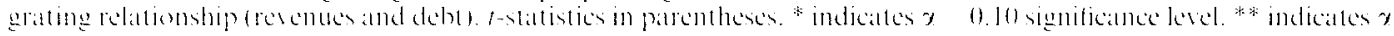

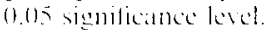


IABLE 4

Engle-Ciranger Cointegration Tests

\begin{tabular}{|c|c|c|c|c|}
\hline & $\alpha$ & 1 & DW & IDI Residual \\
\hline Belgium spending & 0.3103 & $1667 t$ & $(1.29)+$ & 20123 \\
\hline Canata spending & 0.1 .3 .34 & $1.371 \% 4$ & 0.386010 & $2.54+4$ \\
\hline Denmatk spending & $0 .(189)$ & 1.1275 & $0.39(16)$ & 3.1446 \\
\hline f.unland spending & 0.1751 & 1.3130 & 11.9672 & 3.16 .35 \\
\hline Prante spending & 0.2157 & $1+3.32$ & 0.9870 & $\therefore+2+6$ \\
\hline (irecee spending & 0.21801 & $1.7 x=6$ & $(1 .+201)$ & $1.7+23$ \\
\hline laly sponding & 0.0272 & 1.1850 & 0.2314 & 1.16 .37 \\
\hline Vetherdands spending (real per capila) & 0.0013 .2 & 1.20187 & 0.9265 & $2.1117+$ \\
\hline Pontugal spending & 0.04 .51 & 1.14119 & 11.725 & $2 .(6)(1)$ \\
\hline Spain spending & $0.060+2$ & 1.193 .4 & 01.7131 & 1774 \\
\hline Sueden spending & 0.2350 & 1.3917 & 11.301006 & $\therefore(6)+10$ \\
\hline Swilerland >pending & 0.0060 .8 & 1.0423 & $0 .+3012$ & 2.3658 \\
\hline
\end{tabular}

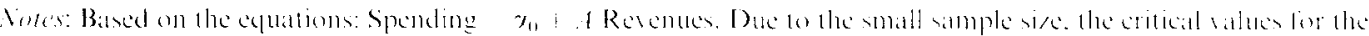
AD) is 2.9() .

Consistent with our sustainability criteriat. $K_{1}$ has an estimated value of 0.31 . The positive $K_{1}$ value indicates that revenues have been raised as debt has mounted. Thus the British fiscal system is also sustainable. However, in this catse the evidence indicates that the government hats not run a Ponzi scheme against the private sector or engaged in a Ponri gamble.

The liscal system of the United States is the last multicointegrated system. Fstimated values of $K_{0}$ and $K_{1}$ liom equation (10) are 1.55 and -1.25 . respectively. The fict that the estimated value of $K_{11}$ is greater than one indicales that on average spending hats been grealer than revenues. ealusing deficits to bo the norm. The negalive value on $K_{1}$ implies that revenues have fallen as debe has risen. Therelore. although the fiscal system is multicointegrated. it does not sattisfy our sustainability criteria. Instead the evidence sugegests that the U.S. policy response is inappropriate given the budget situation. The implication is that the U.S. government has undertaken a Ponzi scheme or engaged in a Ponzi gamble.

Evidence produced in the ECMs of the three multicointegrated systems suggests that spending is more responsive. In the ECMs where estimates of $/ /$ are signilicant they are all negative and in the equations normalied on spending. This suggests that changes in spending decline in response to divergences from the flow equilibrium. The magnitude of $\gamma /$ estimates is generally small, indicaling rather slow speeds of adjustment. Estimates of $\%$ are only significant in the L:K. I:CM. They indicate that spending rises rapidly and reventes fall guite slowly when there are deviations from the debtrevente longrun relationship.

Ilaving rejected multicointegration for the remaining 12 countries. we next test for conventional cointegration between government spending and revenues. Results of these lests accompanied by the corresponding $\mathrm{L}$ : $\mathrm{M}$ s of the cointegrated systems atre reported in Tables 4 and 5 . Results indicate that cointegration is present botween the fiscal variables in Denmark. linland. Fance. Spain. and Sweden. In erery system the estimated walue of $A$ is greater than one. These results indicate that although spending and revenues shate a long-run equilibrium relationship. that relattonship is chatracteriad by persistenty higher spending relative to reventes

Not unlike the multicointegrated ststems. eridence produced by the Le Ms of thesecountries suggests that spending tends to addjust to divergences from the equilibrium relationship. This conclusion is based on negative and signiticant values of $\%$ in the Danish. Finish. Spanish. and Swedish equatlions normalized on spending fand insignificance of $\%$ values in the corresponding equations normalised on revenues). These lindings are consistent with Barros (1979) tax-smoothing arderument. (On the other hand. the french I: C M results indicatedhat resentes rise in response to deviations from the spending-revenue equilibrim. The french 
TABLE 5

Error Correction Models

\begin{tabular}{|c|c|c|c|c|c|}
\hline & $\alpha$ & $\gamma_{1}$ & $\mathbf{B}_{1}$ & $\mathrm{~B}_{2}$ & $r^{2}$ \\
\hline \multicolumn{6}{|c|}{ Denmark } \\
\hline A. & $0.0050 *(1.7394)$ & $0.1529 * *(1.9811)$ & $(1.51 .33 * *(3.200(19))$ & $0.1311(0.8260)$ & 0.22 \\
\hline$\triangle R$ & $\left(0.0074^{* * * 3}(2.180 .3)\right.$ & $0.1(193(1.19 .32)$ & $0.0504(0.3121)$ & $0.229)(1.2152)$ & 0.02 \\
\hline \multicolumn{6}{|c|}{ linland } \\
\hline$A S$ & $0 .(60)+0(1.3753)$ & $\left(0.2012^{* *}(3.0515)\right.$ & $\left(0.5793^{* *}(4.0767)\right.$ & $0.0829)(11.4154)$ & 0.41 \\
\hline$A R$ & $0.110\left(68^{* * *}(2.3140)\right.$ & $0.0] 100(0.1013)$ & $0.0146(0.049) 7)$ & $0.0250(0.126 .31$ & 0.69 \\
\hline \multicolumn{6}{|c|}{ France } \\
\hline A.S & $0.0025(1.1907)$ & $0.2655(1.4602)$ & $0.4406 * *(2.0720)$ & $0.0536(0.1943)$ & 0.11 \\
\hline$A R$ & $0.01121(1.516 .5)$ & $(1.2302 *(1.9196)$ & $0.1455(1.0288)$ & $0.205+(1.1221)$ & 0.21 \\
\hline \multicolumn{6}{|l|}{ Span } \\
\hline A. & $0.00137 *(1.716 .2)$ & $0.3114^{* *}(2.0713)$ & $0.4933 * *(2.5296)$ & $0.0716(0.2984)$ & 0.23 \\
\hline$N R$ & $11.00550 * *(2.6761)$ & $0.0199(0,(0.1274)$ & $0.1220(0.6122)$ & $0.1388,0.56644$ & 0.08 \\
\hline \multicolumn{6}{|c|}{ Sucden } \\
\hline A.S & $0.0060 .2 *(1.96 .39)$ & $\left(1.1777^{*}(2.8709)\right.$ & $(1.4959 * *(3.3959)$ & $0.2973(1.0023)$ & 0.32 \\
\hline$A R$ & $0.0056 *$ (1.56so) & $0.0486(0.8268)$ & $0.1434(1.0336)$ & $0.3915 * *(2.219 \times 1$ & 0.06 \\
\hline
\end{tabular}

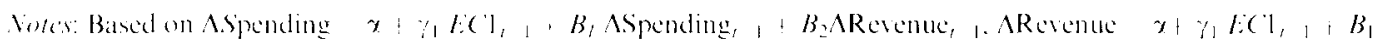
Aspending, B. ARevente; , wherel:Cl is the residual fom the cointegrating retationship. I-stat istics in parentheses. * indicates $x$ (0.10 signilicance level: ** indicates $x$ 0.05 sienificance level.

estimate of $\gamma$ is insignificant in the spending equation. while the y value is positive and significant in the equation normalized on revenue. For all countries the coefficient estimates of $\gamma$ are relatively small. indicating slow speeds of adjustment

In the remainingseven countriesnoevidence of multicointegration or cointegration is present. In Belgium. Canada, Cireece. Italy, the Netherlands and Portugal deficits and debt alecumulation have been the norm. However, revenues have exeeded spending in every period in Switerland. suggesting that surpluses and the accumulation of government savings chatacterizes the Swiss fiscal system.

\section{V1. CONCLUSION}

In this artick we develop a richer se of eriteriat under the more radistic assumption that the discount lactor is variable through time for assessing the sustainability of liscal budgeting practices. We draw on the work of Granger and lece (1989. 1990), Bohn (1995). Ahmed and Rogers (1995). Engsted el al. (1997). Ball et al. (1998) and Haldrup (1998) to derive a more general test for sustainability of the fiscal budgeting process across all stattes of nature. We show that multicontegration of government spending and revenue is an appropriate test for the sustainability of the fiscal process in a stochastic enviromment. The multicointegration condition implies that both the levels and rates of change of the series are tied logether over the long run. In the context of our model. they are linked through a sophisticated policy response mechanism that is derived from the optimal control literature.

We then apply our sustamability eriteria to the fiscal systems of 15 indust rialized countries. Results confirm that intertemporal budgeting strategies vary from combly to country. Norway, the United Kindgom, and the United States are the threecountries that exhibit multicointegration of their systems of fiscal variables. However. the implications for the nature of the budgeting strategy in each country are quite different. Results of multiconintegration tests for Norway and the United Kingdom suggest that these governments have adopted different approaches to liscal budgeting Norway experiencing surpluses and the United Kingdom experiencing deficits. However, both governments" budgeting processes indicate that their fiscal system is characleried by policy responses that are consistent with budgeting sustainability across all states of nature. In the United States on the other hand. the evidence supports the notion that the government hats consistently run deficits and hats not increatsed revenues to accommodate rising debt 
levels. These findings are inconsistent with the sustainability criterial presented here, suggesting that the United States has engaged in a deliberate attempt to execute a Ponzi scheme or a Ponzi gamble.

In the remaining countries the evidence indicates that deficits and debt accumulation have been the norm for all countries except Switzerland. Although the fiscal systems of Denmark. Finland, France, Spain, and Sweden are cointegrated, they exhibit budgeting practices that are consistent with debt aceumulation yet inconsistent with criteria that would enable them to sustain such debt regardless of economic conditions. Therefore. with the exception of Switzerland, the remaining 11 countries either completely lack policy response mechanisms to systematic deficits and debt accumulation or exhibit policy responses that are inadequate for addressing the issue. The evidence is consistent with the conjecture that they, like the United States. have deliberately undertaken a Ponzi gamble attempting to exploit low rates of interest relative to growth or have engaged in a Ponzi scheme. The Swiss evidence suggests that the privalte sector may be running a Ponzi scheme against the government.

\section{REFEREYCHS}

Ahmed. S. and J. H. Rogers. "Gorerment Budgen Delicits and Trade Deficits. Are Present Value Comstratuls Sittisted in I.ong-Term Data?" Jommal

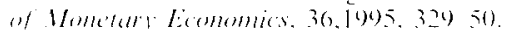

Ball. 1.. D). W. Jimendorl and N (i. Mankin. "The I)

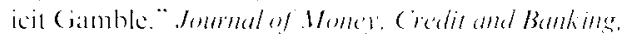
31). 1998.699720 .

Barre. R. M. "On the Determination of Public Debt."

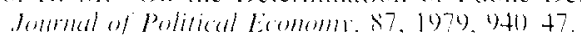

Buhn. I1, "The Sustatinability of Budeet Deficts in a Sto-

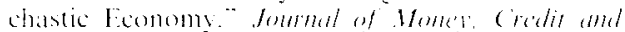
Bumking 27. 1945. 25771.

"The Behavior of (I.S. Public Debe and Delicits."

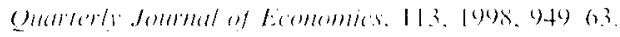

- fiscal Policy and the Mehra-Prosent Purele: (On Helfare Implications of Budged Dedicits Whon Real

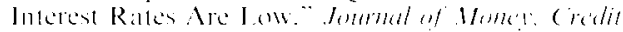
and bamkine 31,1904$) .113$.

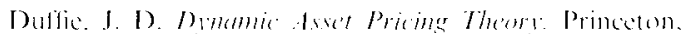
… Princeton Iniversity Press. 1996.

bistert. W. "(irowth Implosions. Dehe Implesions and

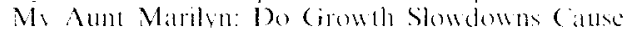
IDhe Criscs?" Workd Bank Working Pilper. 2000).

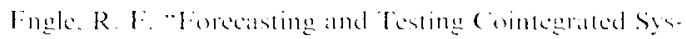

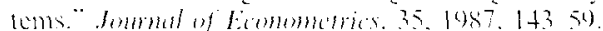

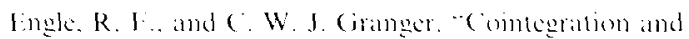
foror Conrection: Representation, Batimation and

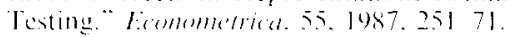

Lngle. R. F. and By ung S. Yoo. "Comtegration of lacomomic Times Sorkes A Surver wht dew Resuls., in

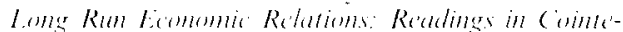

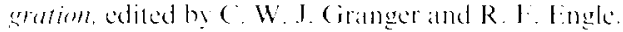
Oxford: Oxford Lniversity Pess. 1949, pp. 23760.

Inested, $T$. and $V$. Haldrup. "Multicontentation in

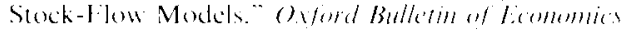
and Statistics. 61. 10909. 23754.

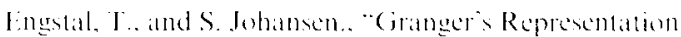

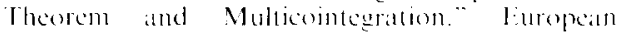
I Iniversily Instinte Working Paper feco. Vo. 97/I5. 1997.

Ingsled. T.. J. Gonfalo, and $\searrow$. Maldrup. "lesting for

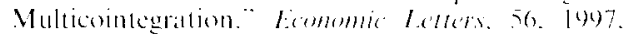
25966.

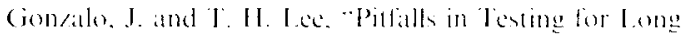

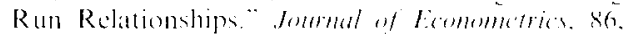
1998.12954.

Granger. ( . W. J. "Investigation of Reproduction. Sales and Inventory Redationships L sing Multicomberatation and Vorn-Simmetric Inror Correction Models."

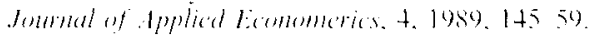

(iranger. ( . W. J. and T. HI lese "Multicontegration." in

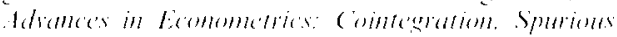

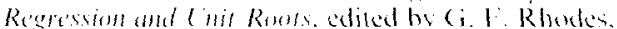

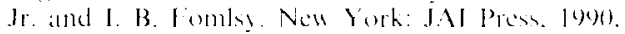
P). 7184.

Hakkiu, ( .. and M. Rush. "Is the Budered Delicit Tor

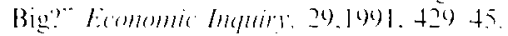

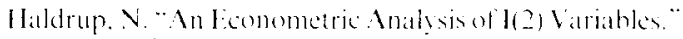

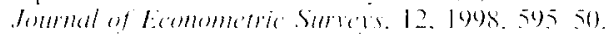

"The Astmptotics of Single-Lquation (iontegrattion Regressions wilh $\mathbf{l}(1)$ and la2) Variables." Jomrnat of Re(1)

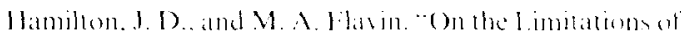
(iosemonent Burrowi-ng: A Framewoth for Lmpir-

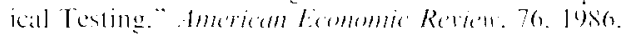
sos 16

llaug. A. A. “Comtegration and (iobermment Borrowing

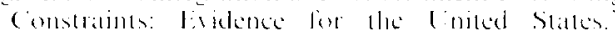

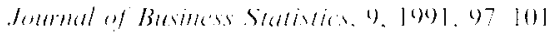

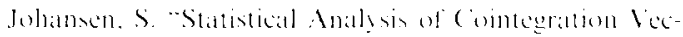

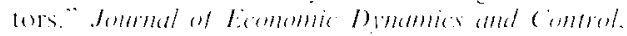
12. $198 \mathrm{sit} .23154$

"Masimum L ikelihond I:stmation and Inference"

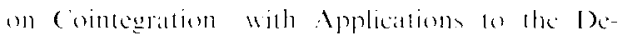

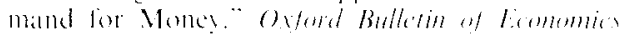

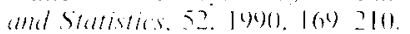

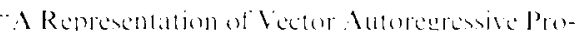

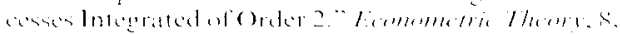
(1) 2 . 18620112

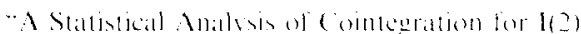

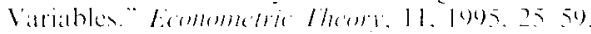

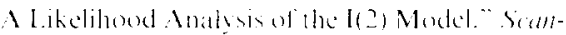

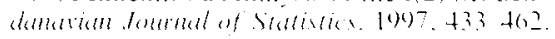

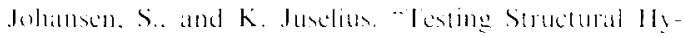

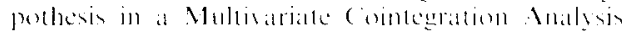
of the PPP and I IP lor the I K.". Intmal of liconomorrics. 53. 1992. $211+4$.

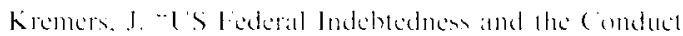

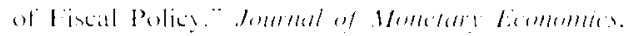
23. 1484. 219 35. 


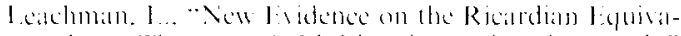
lente Theorent A Malti-coincestation Approate."

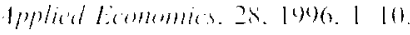

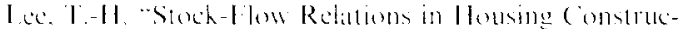

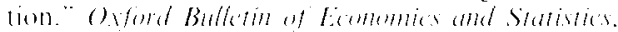
it. 194) +41930

Me( allum. B. T. "Are Bond I intanced Dedicits Intlation-

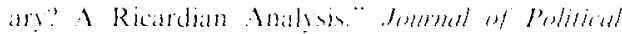

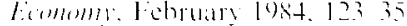

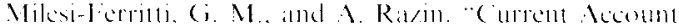

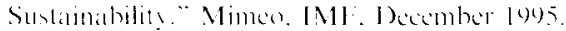

"Sustimalbilits of Peristent (

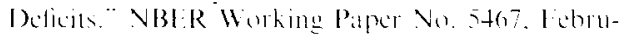
arr 1906

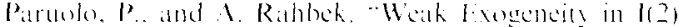

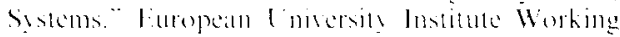
Patper. 1946).

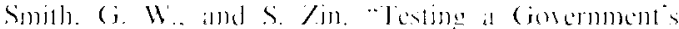

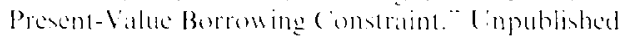

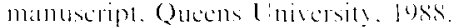

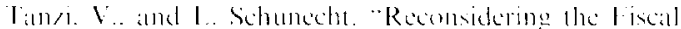
Roke of comernment: The [nternationtal Perspec-

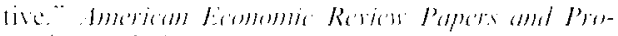
restings, 87. 1997. 164 68.

Trehan. B. and C. F. Wallh. "Testing Intertemporal Bud-

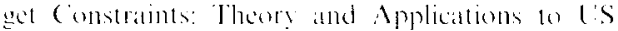
Federial Buded and ( urrent Accoumt Dedicits." Fed-

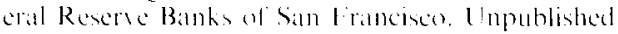
mantsuript. 1900)

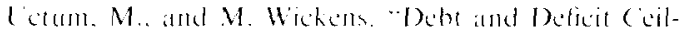
ingse and Sustamability of liscal Policies: An Intertemporial Analssis" lederal Reseme Bank. Bank of Vew York Rexearch Paper Vo, 9615. June 19)

Von Ilagem. J. and I. J Marden. National Budget Pro-

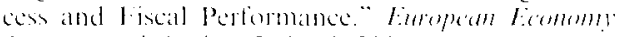

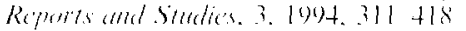

Wiken, D. W. "The Sustamability of (josermment Deticits: Implications of the Present Valde-Borrowing

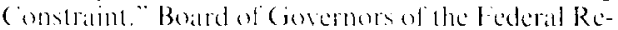
serve System Worthing Paper Vo. 77: 9. 1987.

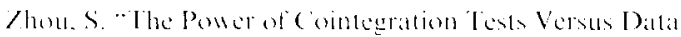

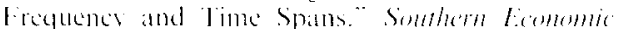
Jommal. 67. 2001.906 21 